\title{
Seepage and Slope Stability Analysis of Myittha Multipurpose Dam Project, Gangaw Township, Magway Region, Myanmar
}

\author{
Hla Myat Htwe ${ }^{1 *}$, Tun Naing ${ }^{2}$ \\ ${ }^{1}$ Applied Geology Department, University of Yangon, Yangon, Myanmar \\ ${ }^{2}$ Engineering Geology Department, Yangon Technological University, Yangon, Myanmar
}

"Corresponding author: hlamh.tt@gmail.com

\begin{abstract}
Myittha Multipurpose Dam Project is constructed on Myittha River to be implemented for hydropower production of installed power $40 \mathrm{MW}$ and average annual energy 170 million $\mathrm{kWh}$ for regional development and irrigation network of 12,000 acres. Myittha dam has two portions of embankment: main dam (rockfill zone type) and long saddle dam (homogeneous type). The purpose of this paper is the evaluation of seepage and slope stability conditions of Myittha embankments (Myanmar) based on three different cases of operations: end of construction before filling the reservoir, steady state seepage and rapid drawdown of the reservoir. Seepage and slope stability analysis were done in two ways: analytical and computer approaches. Analytically, seepage analysis was done by using Laplace equation based on Darcy's law and slope stability analysis was done by using Ordinary Method of Slices and Bishop Simplified Method. This analytical approach was used to access based on the earthen dam details and geotechnical design parameters of embankment materials. On this research, SLOPE/W and SEEP/W soft-wares were used as computer approach. The analysis results presented in this research confirm the safety of Myittha dam against combined seepage and slope stability under all cases of operation.
\end{abstract}

Keywords - Main dam, Long saddle dam, Analytical and computer approaches, Ordinary method of slice, Bishop simplified method.

\section{INTRODUCTION}

$\mathrm{T}$ he purpose of this paper is the evaluation of seepage and slope stability analysis of Myittha dam, presentation of back analysis for seepage and stability of embankment slope. Earth dams are very huge earth structures which store a large quantity of water in the reservoir upstream. Their failure may cause vast damage, catastrophe and loss of human lives. About $38 \%$ of the earth dam failures in the past occurred due to seepage. If the seepage is suitable controlled, it does not cause any harm other than loss of some water. If the seepage is uncontrolled, it may lead to piping and the subsequent failure of the earth dam. And hence seepage analysis of embankment dam is of greater importance. Slope stability analysis of earth dam is very important to ascertain the stability of the structure. The stability of the earth dam depends on its geometry, its components, material properties of each component and the forces to which it is subjected. Analytically, stability analysis of Myittha dam body is performed by Ordinary Method of Slices and Bishop Simplified Method. Geo-studio software is one of the geotechnical software and it is based on the finite element that can be considering the analysis of seepage and slope stability analysis. In this project for determination of seepage analysis, Myittha dam has been done by SEEP/W software. The slope stability analysis of Myittha dam has been done by SLOPE/W software and is used in under different conditions to evaluate slope stability. This software not only the superiority to the graphic method and manual calculations, but also regarding the time we can gain good results.

\section{A. Location}

The Myittha Multipurpose Dam Project is located at about 2.5 miles far from the southwest of Pyintha Village, Gangaw Township, Magway Division, Myanmar. It is one of the projects to be implemented for hydropower production of installed power $40 \mathrm{MW}$ and average annual energy is 170 million $\mathrm{kWh}$ for regional development and irrigation network of 12,000 acres. The dam built on sedimentary rocks of Thanbaya Formation (Triassic age). The Myittha Dam has two portions of embankment, namely main dam (rock fill zone type, $62.484 \mathrm{~m}$ height and $792.48 \mathrm{~m}$ length) and long saddle dam (homogeneous type, $62.484 \mathrm{~m}$ height and 8,854.44 $\mathrm{m}$ length)[2]. The saddle dam is a kind of independent main dam. It is constructed on Myittha River and the reference index map number is $84 \mathrm{~K} / 1$ and grid number is 267,736. Location map of Myittha multipurpose dam project is shown in Figure (1).

\section{B. Myittha dam site geology}

The dam site is located on the very high mountainous ranges and Myittha River starts from Chin Mountain Ranges (above 4,500 ft to 9,000 ft high) and flows from south to north with spreading water sheet flow. The safety and stability of the dam and reservoir mainly depend on geology and engineering properties of soil and rock of the site.

The general geology around the Myittha dam site area (Figure 2) is constituted Mesozoic rocks of Thanbaya Formation, Cenozoic rocks of Irrawaddy Formation and 


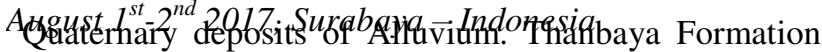
(Middle - Upper Triassic) is widely distributed in the dam site area and is mainly composed of medium to thick bedded, grey to bluish grey, quartzose sandstone interbedded with dark grey to black slate and grey to greenish grey slaty shale or shale. These rocks are situated layer by layer. The beds are much sequeezed and contorted, universally high to vertical dips. The vertical dipping from east to south-east with $40^{\circ}$ to $75^{\circ}$ incline and one layer to another layer is about $2^{\prime \prime}$ to $1 \mathrm{ft}$ thickness. The Triassic strata were variably deformed and locally metamorphosed up to upper green-schist facies. Irrawaddy Formation (Upper Miocene - Pliocene) uncomformably lies on the Thanbaya Formation and is mainly composed of loose, yellowish brown sandstone which contains fossil woods. Quaternary deposit of Alluvium is mainly composed mixture of cobbles, pebbles, gravels and fragments of quartz, slate and shale. The regional structural trend of rock strata is generally NNE - SSW direction. CL grade rock mass appears at shallow depth in the most dam site area. CM grade rock mass of sandstone is found as dam foundation layer [2].

\section{METHODOLOGY}

In this project, the seepage and slope stability analyses are done in two ways such as analytical approach and computer approach.

\section{A. Analytical approach}

The analytically the seepage analysis is calculated by using Darcy's law, and the slope stability analysis is done by using Ordinary method of slices and Bishop simplified method[5]. This analytical approach is done based on the earthen dam details and with their material properties.

\section{B. Computer approach}

In order to achieve the objectives of this study SEEP/W and SLOPE/W softwares are used for evaluating the performance of dams. The product

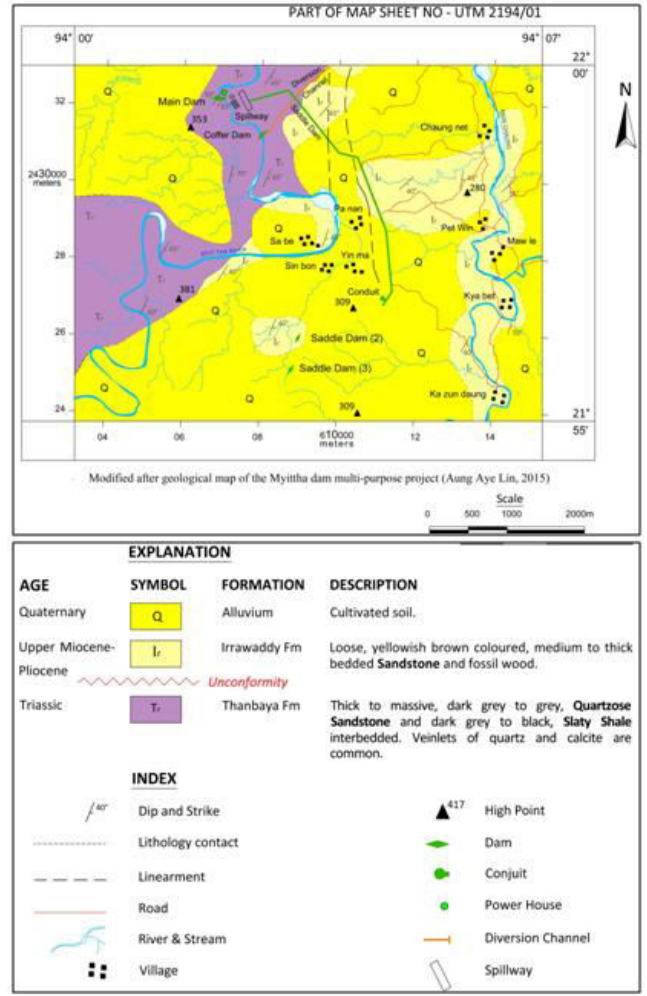

Figure 2. Geological map of Myittha multipurpose dam

SEEP/W is used for the analysis of seepage. The product SLOPE/W is calculated the analysis of slope stability and pore-water pressure conditions, soil properties, analysis of methods and loading conditions [7].

\section{RESULTS AND DISCUSSIONS}

Myittha dam has two portions of embankment main dam (rock fill zone type) and long saddle dam (homogeneous type). Basic dimensions, elevations, typical slope, cross-section of Myittha main dam and saddle dam are shown in Figures (3) and (5) [2].

A. Myittha main dam

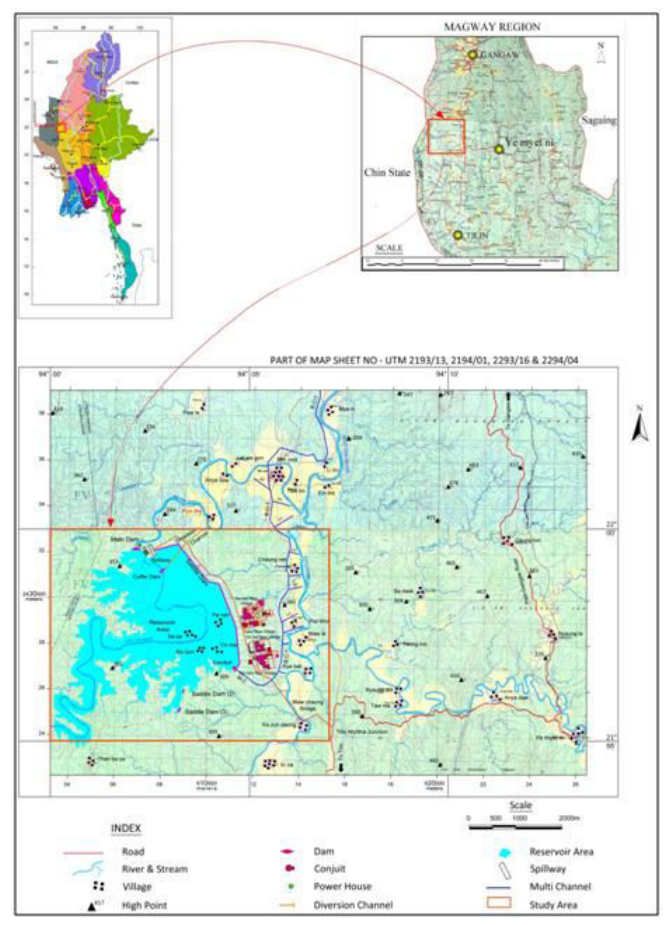

Figure 1. Location map of Myittha multipurpose dam 
The height of the main dam is $205 \mathrm{ft}$ and its length is 2,300 $\mathrm{ft}$. Myittha dam location at the river portion is RL. $825 \mathrm{ft}$ and the dam crest level is RL. 1,030 $\mathrm{ft}$. The various components of the section for Myittha dam are rock zone (I \& VII), transition zone (II \& VI), filter zone (III \& V) and selected impervious zone (IV). Embankment zone section of Myittha main dam is

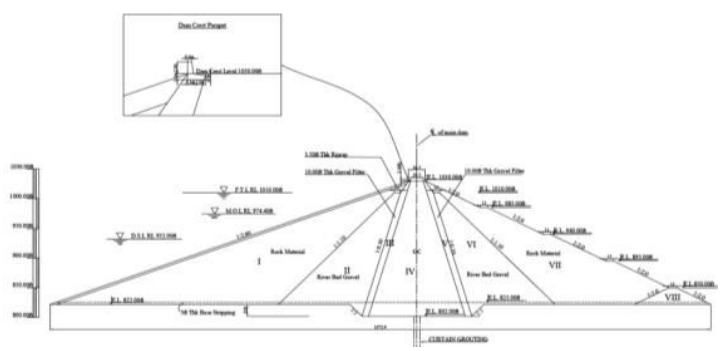

Figure 3. Basic dimensions, elevations, slopes and typical cross-section of Myittha main dam

shown in Figure (4). Main dam has been constructed by rock fill zone type with the crest elevation EL. $313.95 \mathrm{~m}$ $(1,031.3 \mathrm{ft})$. Full water level is decided according to the simulation of reservoir operation and its elevation is F.W.L $307.85 \mathrm{~m}(1,010 \mathrm{ft})$. Dead water level is calculated according to the simulation of reservoir operation and its elevation is MOL. $284.08 \mathrm{~m}$ (932.0 ft). Estimation of high water level is computed by using 1,000 years return period of flood and it is considered storage effect of the reservoir. Its elevation is HWL. $312.34 \mathrm{~m}(1,024.74 \mathrm{ft})$. Slopes of dam (the upstream and the downstream sides) are 1:2.8 and 1:2.0. Depth of reservoir at FWL is $56.85 \mathrm{~m}$. The earthquake coefficient $\mathrm{K}=0.15$ is almost 200 year return period as the results of Iwai method. The result of the seismic coefficient analysis is $\mathrm{K}=0.15$ at Myittha dam (zone type fill dam on rock foundation). In the stability analysis of Myittha

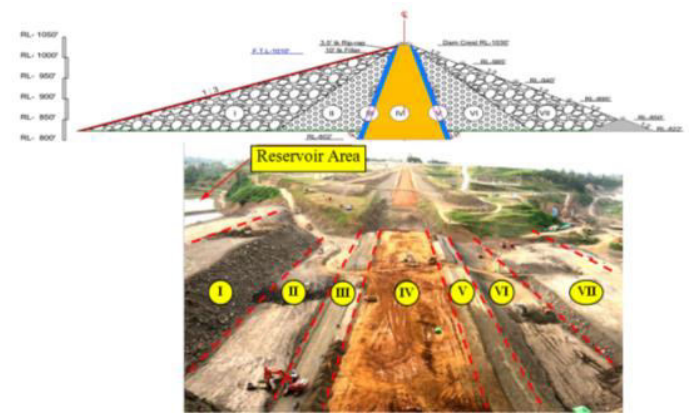

Figure 4. Embankment zone section of Myittha main dam

dam, earthquake coefficient $\mathrm{k}=0.15$ is used.

\section{B. Myittha saddle dam}

The height of saddle dam is $115 \mathrm{ft}$ and its length is $27,450 \mathrm{ft}$. The saddle dam body is the homogeneous type, consisting of selected impervious zone (GC) and filter zone (river gravel materials). Saddle dam has been constructed by homogeneous dam type with the crest elevation EL. $313.95 \mathrm{~m}(1,030 \mathrm{ft})$. More than $80 \%$ of the maximum section of embankment is composed of

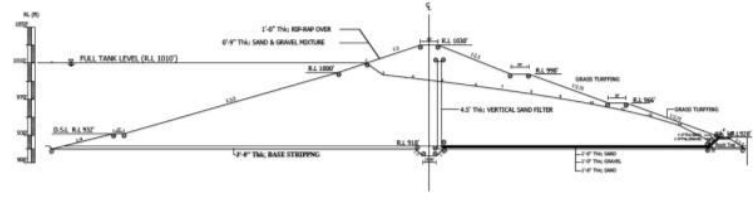

Figure 5. Basic dimensions, elevations, slopes and typical cross-section of Myittha saddle dam

homogeneous material. Water tightness and stability of dam body are kept by whole section. Full water level is decided according to the simulation of reservoir operation and its elevation is F.W.L $307.85 \mathrm{~m}$ (1,010 ft). Dead water level is calculated according to the simulation of reservoir operation and its elevation is MOL. $284.08 \mathrm{~m}$ (932.0 ft). Estimation of high water level is computed by using 1,000 years return period of flood and it is considered storage effect of the reservoir. Its elevation is HWL. $312.34 \mathrm{~m}(1,024.74 \mathrm{ft})$. Slopes of dam (the upstream and the downstream sides) are 1:3.5 and 1:2.75. Depth of reservoir at FWL is $56.85 \mathrm{~m}$.

\section{Design values of embankment materials}

For the seepage and slope stability analysis of the Myittha dam, the laboratory tests of impervious and rock materials have been performed. The design values of the dam filling materials were decided by the soil test results. For each embankment zone and foundation layer, design shear strengths are selected such that two-thirds of the test values exceed the design values [11]. The Myittha dam design value of filling materials based on the soil test results are shown in Table (1\&2).

\section{Seepage analysis}

Earth dams have always been associated with seepage as they impound water it [3]. The water seeks paths of least resistance through the dam and its foundation. Seepage will become a problem along if it carries dam material also along with it. Seepage must be controlled to prevent the erosion of embankment or its foundation. Seepage analysis is required to determine the quantity of water passing through the body of the earth dam and the foundation. The distribution of pore water pressure can also be obtained by the seepage analysis. Different methods such as analytical method and graphical method based on the flow net construction are used in the analysis of seepage for Myittha main dam and long saddle dam.

(a) Determination of flow per unit length of embankment, $q$

The first step is the determination of the upper flow line or the line of seepage boundary and the length of the seepage exit face on the downstream slope of the earth dam. This provides all necessary boundary conditions for flow net construction. Figure (6) provides the nomenclature and formulas for drawing the line of seepage (Casagrande, 1937) and exit face and determining the quantity of seepage per unit length of embankment, q [9].

(b) Seepage analysis by using analytical approach 


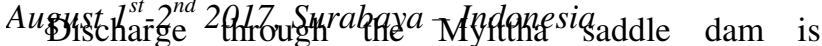
determined by three conditions such as without any drainage system, with a horizontal drainage blanket and with a toe drain. For the slope angle $(\alpha)$ less than $30^{\circ}$ without any drainage system shown in figure (7), Schaffernak-Van Iterson method is used to determine the discharge. For the case of $\alpha=180^{\circ}$ and earth dam with horizontal drain on impervious foundation, Kozeny equation is used to obtain the value of discharge. If the earth dam is constructed with toe drain on impervious

\begin{tabular}{|c|c|c|c|c|c|}
\hline Materials & & $\begin{array}{c}\text { Impervious } \\
\text { zone }\end{array}$ & $\begin{array}{c}\text { Filter } \\
\text { zone }\end{array}$ & $\begin{array}{c}\text { Transition } \\
\text { zone }\end{array}$ & Rock zone \\
\hline $\begin{array}{l}\text { Specific } \\
\text { gravity }\end{array}$ & Gs & 2.66 & 2.44 & 2.39 & 2.39 \\
\hline \multirow[t]{3}{*}{$\begin{array}{l}\text { Water } \\
\text { content }\end{array}$} & W & 15.5 & 5 & 47 & 4.7 \\
\hline & Dry $\gamma_{\mathrm{d}}$ & 1.77 & 1.91 & 1.949 & 1.949 \\
\hline & Wet $\gamma$ & 2.044 & 2.000 & 2.040 & 2.040 \\
\hline \multirow[t]{2}{*}{$\begin{array}{l}\text { Density } \\
\left(\text { ton } / \mathrm{m}^{3}\right)\end{array}$} & $\begin{array}{c}\text { Saturated } \\
\gamma_{\mathrm{sat}}\end{array}$ & 2.014 & 2.127 & 2.133 & 2.133 \\
\hline & $\begin{array}{c}\text { Submerged } \\
\gamma_{\text {sub }}\end{array}$ & 1.014 & 1.127 & 1.133 & 1.133 \\
\hline \multirow[t]{2}{*}{$\begin{array}{l}\text { Shear } \\
\text { strength }\end{array}$} & $\mathrm{c}\left(\mathrm{ton} / \mathrm{m}^{2}\right)$ & 5.5 & 0.0 & 4.4 & 3.8 \\
\hline & $\varnothing\left(^{\circ}\right)$ & 20.0 & 35.0 & 35.0 & 40.0 \\
\hline Permeability & $\mathrm{k}(\mathrm{cm} / \mathrm{s})$ & $2.7 \times 10^{-6}$ & $\begin{array}{c}1.41 \mathrm{x} \\
10^{-2}\end{array}$ & $3.08 \times 10^{-2}$ & $1.42 \times 10^{-1}$ \\
\hline
\end{tabular}

foundation, discharge per unit length can calculate the method of A. Casagrande [3].

(c) Seepage analysis by using computer approach The seepage analysis is performed by using SEEP/W software in earthen dam. Earthen dam dimensions and soil properties are input data as describe in Figures (3\& 5) and Table (1\& 2).

Table 1. Design values of main dam filling materials

Table 2. Design values of saddle dam filling materials

\begin{tabular}{llcc}
\hline \multicolumn{2}{c}{ Materials } & Impervious Core & Filter \\
\hline Specific gravity & Gs & 2.66 & 2.44 \\
Water content & $\mathrm{w}(\%)$ & 15.2 & 5.0 \\
Density $\left(\mathrm{tf} / \mathrm{m}^{3}\right)$ & Dry $\gamma_{\mathrm{d}}$ & 1.77 & 1.91 \\
& Wet $\gamma$ & 2.039 & 2.00 \\
Density $\left(\mathrm{tf} / \mathrm{m}^{3}\right)$ & Saturated $\gamma_{\text {sat }}$ & 2.104 & 2.127 \\
& Submerged $\gamma_{\text {sub }}$ & 1.104 & 1.127 \\
\multirow{2}{*}{ Shear strength } & $\mathrm{c}\left(\right.$ ton $\left./ \mathrm{m}^{2}\right)$ & 5.5 & 0.0 \\
& $\varnothing\left({ }^{\circ}\right)$ & 20.0 & 35.0 \\
\hline
\end{tabular}

\begin{tabular}{llll}
\hline $\begin{array}{l}\text { Permeability } \\
\text { Remark }\end{array}$ & $\mathrm{k}(\mathrm{cm} / \mathrm{s})$ & $2.7 \times 10^{-6}$ & $1 \times 10^{-3}$ \\
\hline
\end{tabular}

\section{(d) Discussions}

Summary results of discharge per unit length are shown in table (3). Based on the results of seepage through dam, the seepage values of main dam are more than that of saddle dam. All values are within the permissible limit.

\section{E. Slope stability analysis}

The stability analysis is largely a trial-and-error process, accomplished by numerical or graphical methods. Stability of an embankment was evaluated for construction and operating conditions utilizing the in-situ engineering properties of the foundation and embankment materials and pertinent geologic information. While considering the stability of Myittha dams, there are three generally recognized critical stages based on pore pressure conditions such as end of construction, steady state seepage, and rapid drawdown. Construction pore pressures usually attain their maximum value when the full height of the embankment has been constructed. The steady state seepage condition is attained after the reservoir remains filled for a long time and the pore pressure can be estimated from a flow net. Rapid lowering of the reservoir water level produces the third critical condition, particularly for slow draining soils. The stability of upstream slope should be examined for the end of construction and rapid drawdown conditions and that of the downstream slope for the

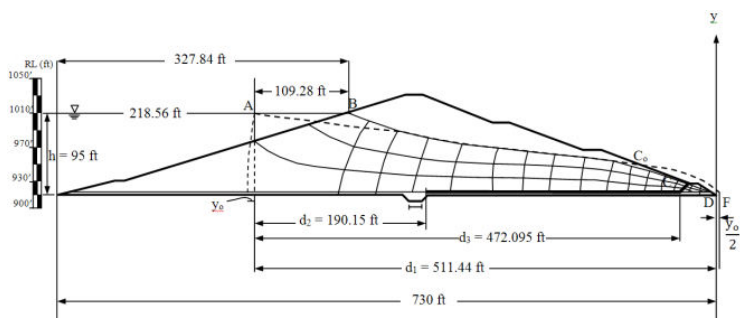

Figure 7. Basic dimensions, elevations, slopes, seepage line and flow net construction of saddle dam without any drainage system

construction and steady state conditions. For the Myittha dam stability analysis of slopes, the Swedish circle method and Simplified Bishop's method are used. 
The Third International Conference on Civil Engineering Research (ICCER)

August $1^{\text {st }}-2^{\text {nd }} 2017$, Surabaya - Indonesia

Table 3. Summary results of discharge through Myittha main dam and saddle dam

\begin{tabular}{|c|c|c|c|c|c|c|c|c|}
\hline \multirow{3}{*}{$\begin{array}{c}\text { Methods } \\
\text { used in } \\
\text { seepage } \\
\text { analysis } \\
\text { of } \\
\text { Myittha } \\
\text { dams }\end{array}$} & \multicolumn{8}{|c|}{ Flow per unit length } \\
\hline & \multirow{2}{*}{\multicolumn{2}{|c|}{ Main Dam }} & \multicolumn{6}{|c|}{ Saddle Dam } \\
\hline & & & \multicolumn{2}{|c|}{$\begin{array}{c}\text { Without any } \\
\text { drainage } \\
\text { system }\end{array}$} & \multicolumn{2}{|c|}{$\begin{array}{c}\text { With a } \\
\text { horizontal } \\
\text { drainage } \\
\text { blanket }\end{array}$} & \multicolumn{2}{|c|}{$\begin{array}{l}\text { With a toe } \\
\text { drain }\end{array}$} \\
\hline \multirow{3}{*}{$\begin{array}{c}\text { Graphical } \\
\text { method }\end{array}$} & \multicolumn{8}{|c|}{$\mathrm{ft}^{3} / \mathrm{mingal} / \mathrm{min} / \mathrm{ft}^{3} / \mathrm{min} \mathrm{gal} / \mathrm{min} / \mathrm{ft}^{3} / \mathrm{min} \mathrm{gal} / \mathrm{min} \mathrm{ft}^{3} / \mathrm{min} \mathrm{gal} / \mathrm{min} /$} \\
\hline & $/ \mathrm{ft}$ & $\mathrm{t}$ & $/ \mathrm{ft}$ & $\mathrm{ft}$ & $/ \mathrm{ft}$ & $/ \mathrm{ft}$ & $/ \mathrm{ft}$ & $\mathrm{ft}$ \\
\hline & $\begin{array}{c}4.92 \mathrm{x} \\
10^{-4}\end{array}$ & $\begin{array}{c}3.68 \mathrm{x} \\
10^{-3}\end{array}$ & $\begin{array}{c}1.01 \mathrm{x} \\
10^{-4}\end{array}$ & $\begin{array}{c}7.56 \mathrm{x} \\
10^{-4}\end{array}$ & $\begin{array}{c}1.26 \mathrm{x} \\
10^{-4}\end{array}$ & $\begin{array}{c}9.45 \mathrm{x} \\
10^{-4}\end{array}$ & $\begin{array}{c}1.17 \mathrm{x} \\
10^{-4}\end{array}$ & $\begin{array}{c}8.72 \mathrm{x} \\
10^{-4}\end{array}$ \\
\hline $\begin{array}{c}\text { Analytical } \\
\text { method }\end{array}$ & $\begin{array}{c}4.89 \mathrm{x} \\
10^{-4}\end{array}$ & $\begin{array}{c}3.66 \mathrm{x} \\
10^{-3}\end{array}$ & $\begin{array}{c}0.53 \mathrm{x} \\
10^{-4}\end{array}$ & $\begin{array}{c}3.96 \mathrm{x} \\
10^{-4}\end{array}$ & $\begin{array}{c}1.19 \mathrm{x} \\
10^{-4}\end{array}$ & $\begin{array}{c}8.92 \mathrm{x} \\
10^{-4}\end{array}$ & $\begin{array}{c}0.50 \mathrm{x} \\
10^{-4}\end{array}$ & $\begin{array}{c}3.78 \mathrm{x} \\
10^{-4}\end{array}$ \\
\hline $\begin{array}{c}\text { Computer } \\
\text { method } \\
\text { by } \\
\text { SEEP/W } \\
\text { software }\end{array}$ & $\begin{array}{c}5.49 \mathrm{x} \\
10^{-4}\end{array}$ & $\begin{array}{c}4.11 \mathrm{x} \\
10^{-3}\end{array}$ & $\begin{array}{c}0.84 \mathrm{x} \\
10^{-4}\end{array}$ & $\begin{array}{c}6.32 \mathrm{x} \\
10^{-4}\end{array}$ & $\begin{array}{c}1.54 \mathrm{x} \\
10^{-4}\end{array}$ & $\begin{array}{c}1.16 \mathrm{x} \\
10^{-4}\end{array}$ & $\begin{array}{c}0.98 \mathrm{x} \\
10^{-4}\end{array}$ & $\begin{array}{c}7.32 \mathrm{x} \\
10^{-4}\end{array}$ \\
\hline
\end{tabular}

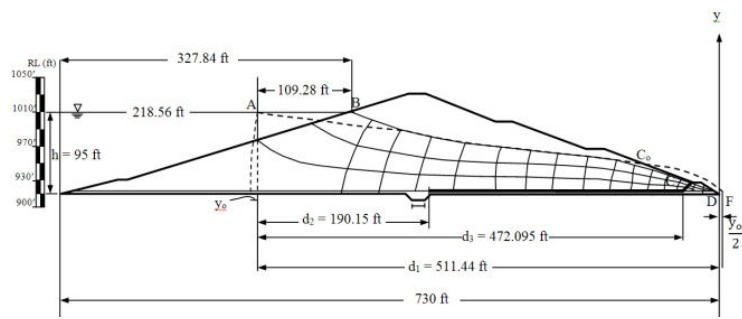

Figure 7. Basic dimensions, elevations, slopes, seepage line and flow net construction of saddle dam without any drainage system

\section{(a) Ordinary method of slice}

This analysis is based on a circular slip circle. In the effective stress method, the pore pressures along the assumed failure surface are estimated and the analysis utilizes effective strength parameters $c^{\prime}$ and $\varnothing^{\prime}$ obtained from a $\mathrm{CD}$ shear test or a $\mathrm{CU}$ test with pore pressure

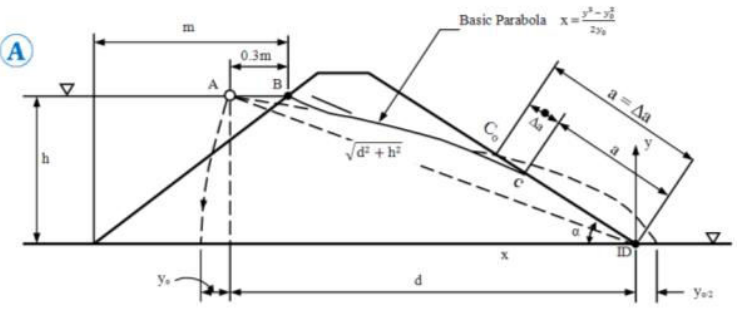

(B)

\begin{tabular}{|c|c|c|c|c|}
\hline$\alpha$ & Method & Equati & $\begin{array}{r}\text { sed fo } \\
\text { leı }\end{array}$ & $\begin{array}{l}\text { lischarge per unit } \\
\text { h }\end{array}$ \\
\hline$<30$ & $\begin{array}{l}\text { Schaffernak - } \\
\text { Van Iterson }\end{array}$ & d & $\mathrm{d}^{2}$ & $\mathrm{~h}^{2}$ \\
\hline
\end{tabular}

$\leqq 90^{\circ}$ L. Casagrande

$a=S_{o}-\sqrt{S_{o}^{2}-\frac{h^{2}}{\sin ^{2} \alpha}}$

For $\alpha \leqq 60^{\circ}$, Use $S_{0}=\sqrt{d^{2}+h^{2}}$. For $60^{\circ}<\alpha<90^{\circ}$, use measured $\mathrm{S}_{\mathrm{o}}=\widehat{\mathrm{AC}}+\overline{\mathrm{CD}}$ $\mathrm{q}=\mathrm{k} \mathrm{a} \sin ^{2} \alpha$

$180^{\circ}$ Kozeny

$$
\begin{aligned}
& a_{o}=\frac{y_{o}}{2}=\frac{1}{2}\left(\sqrt{d^{2}+h^{2}}-d\right) \\
& q=2 k a_{0}=k y_{0}
\end{aligned}
$$

$30^{\circ}$ to A. Casagradne Determine $(\mathrm{a}+\Delta \mathrm{a})$ as the intersection of the $180^{\circ} \quad$ basic parabola and dam slope. Then determine $\Delta \mathrm{a}$ from $\mathrm{C}$ value on below figure 4-C.

$\mathrm{q}=\mathrm{k}$ a $\sin ^{2} \alpha$ or $\mathrm{q}=\mathrm{ky}_{0}=\mathrm{k}\left(\sqrt{\mathrm{d}^{2}+\mathrm{h}^{2}}-\mathrm{d}\right)$

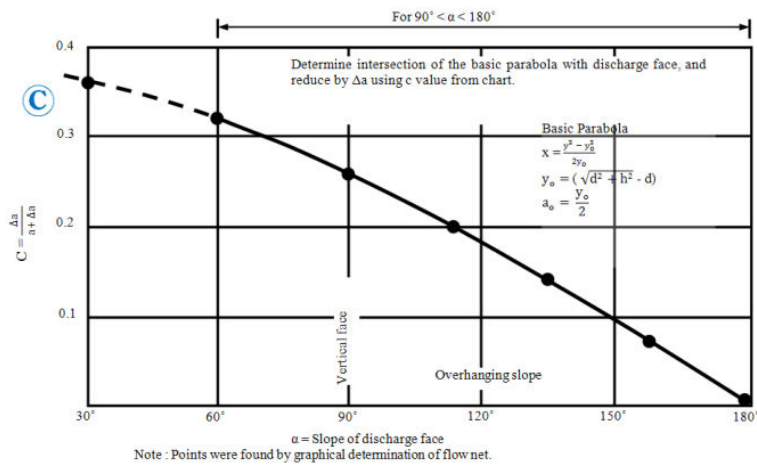

Figure 6. A-Nomenclature, B-Formulas and C-Value of C based on $\alpha$ (degree) [9]

measurements. In the total stress method, the shear strength is determined from UU tests. For a "c $-\varnothing$ " soil, the shear strength depends on the normal reaction. The weight $(\mathrm{W})$ is resolved into normal $(\mathrm{N}=\mathrm{W} \cos \theta)$ and tangential $(\mathrm{T}=\mathrm{W} \sin \theta)$ components. The sliding force is the tangential component $(\mathrm{T})$ and the resisting force is

Table 4. Slope stability analysis of Myittha main dam (Reservoir full condition)

\begin{tabular}{|c|c|c|c|c|c|c|c|c|c|c|c|c|}
\hline $\begin{array}{l}0 \\
z \\
\frac{0}{n}\end{array}$ & 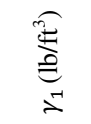 & 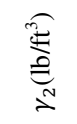 & $\underbrace{E}_{\Xi}$ & $\underset{\Xi}{\Theta}$ & $\underbrace{E}_{0}$ & $\begin{array}{l}\hat{\theta} \\
3\end{array}$ & $\begin{array}{l}\overparen{ఖ} \\
\stackrel{d}{0} \\
\stackrel{0}{0}\end{array}$ & $\begin{array}{l}0 \\
0 \\
0 \\
0 \\
3\end{array}$ & $=\frac{\frac{N}{3}}{\frac{1}{3}}$ & $\begin{array}{l}0 \\
\tilde{U} \\
\infty \\
0\end{array}$ & & $\begin{array}{l}0 \\
\cdot \Xi \\
3 \\
3\end{array}$ \\
\hline 1 & 127.27 & - & 21.56 & - & 33.7965 & $92,735.61$ & $42^{\circ}$ & $68,911.83$ & - & 45.48 & $51,227.31$ & $62,049.40$ \\
\hline 2 & 127.27 & 68.91 & 35.94 & 10.78 & 33.7965 & $179,693.75$ & $35^{\circ}$ & $147,205.12$ & 672.672 & $27,735.62$ & $46,476.14$ & $103,072.34$ \\
\hline 3 & 127.27 & 68.91 & 28.75 & 25.16 & 33.7965 & $182,257.36$ & $29^{\circ}$ & $159,402.29$ & $1,569.984$ & $60,668.76$ & $43,529.51$ & $88,358.37$ \\
\hline 4 & 127.27 & 68.91 & 17.97 & 39.53 & 33.7965 & $169,356.09$ & $23^{\circ}$ & $155,892.28$ & $2,466.672$ & $90,567.61$ & $41,359.50$ & $66,167.42$ \\
\hline 5 & 127.27 & 68.91 & 17.97 & 46.72 & 33.7965 & $186,101.01$ & $16^{\circ}$ & $178,898.90$ & $2,915.328$ & $102,498.56$ & $39,604.47$ & $51,289.44$ \\
\hline 6 & 127.27 & 68.91 & 7.19 & 50.31 & 33.7965 & $148,094.01$ & $12^{\circ}$ & $144,850.75$ & $3,139.344$ & $108,464.84$ & $38,919.20$ & $30,788.74$ \\
\hline 7 & 127.27 & 68.91 & 7.19 & 43.13 & 33.7965 & $131,372.39$ & $7^{\circ}$ & $130,387.10$ & $2,691.312$ & $91,639.10$ & $38,355.76$ & $16,014.29$ \\
\hline 8 & 127.27 & 68.91 & 7.19 & 35.94 & 33.7965 & $114,627.48$ & $0^{\circ}$ & $114,627.48$ & $2,242.656$ & $75,793.92$ & $38,070.24$ & 0.0000 \\
\hline 9 & 127.27 & 68.91 & 3.59 & 25.16 & 33.7965 & $74,037.14$ & $-8^{\circ}$ & $+73,318.98$ & $1,569.984$ & $+53,579.95$ & $38,443.32$ & $-10,305.97$ \\
\hline \multirow[t]{2}{*}{10} & 127.27 & 68.91 & 10.78 & - & 33.7965 & $46,367.80$ & $-13^{\circ}$ & $+45,180.78$ & - & +34.69 & $39,071.48$ & $-10,432.76$ \\
\hline & & & & & & $\Sigma$ & & $1,218,675.51$ & & $614,480.84$ & $415,056.93$ & $397,001.27$ \\
\hline
\end{tabular}


the shear strength which is the sum of the cohesive and frictional strengths at the base of each slice. If effective stress parameters are used, the normal force is reduced by the water force $\mathrm{U}=\mathrm{u} .1$, where $\mathrm{u}$ is the average pore pressure on the slice bottom. The calculations are set out in a tabular form. The equations used in calculation of slope stability are

$$
\begin{gathered}
\mathrm{F}_{\mathrm{S}}=\frac{\mathrm{cL}+\tan \emptyset \Sigma \mathrm{W} \cos \theta}{\Sigma W \sin \theta} \quad \text { and } \\
\mathrm{F}_{\mathrm{S}}=\frac{c^{\prime} L+\tan \emptyset \Sigma(W \cos \theta-u . l)}{\Sigma W \sin \theta}
\end{gathered}
$$

\section{(b) Bishop simplified method}

The geotechnical design parameters shown in Figures ( $2 \& 3)$ and Tables ( $\&$ 2) are used in Bishop simplified method for the analysis of slope stability of Myittha dam[4]. The equations used in calculation of slope stability are

$$
\begin{aligned}
& \mathrm{F}_{\mathrm{s}}=\frac{1}{\Sigma W \sin \theta} \sum\left[\frac{\left\{\mathrm{c}^{\prime} \mathrm{b}+(\mathrm{W}-\mathrm{ub}) \tan \phi\right\} \sec \theta}{1+\left(\tan \theta \tan \phi^{\prime}\right) / \mathrm{F}}\right] \\
& \mathrm{F}_{\mathrm{s}}=\frac{1}{\Sigma W \sin \theta} \sum\left[\frac{\left\{\mathrm{c}^{\prime} \mathrm{b}+\mathrm{W}\left(1-\gamma_{\mathrm{u}}\right) \tan \phi\right\} \sec \theta}{1+\left(\tan \theta \tan \phi^{\prime}\right) / \mathrm{F}}\right]
\end{aligned}
$$

Although it is expressed in terms of effective stress parameters, it can be used for total stress parameters also. dam and angle of slope used in slope stability analyses are shown in Figures $(2 \& 3)$ and Tables $(1 \& 2)$. The calculations based on Figure (8) are set out in tabular forms shown in Tables ( 4 \& 5).

From Table 4. slope stability analysis of Myittha main dam (Reservoir full condition)

$$
\begin{aligned}
\mathrm{F}_{\mathrm{S}} & =\frac{\tan \emptyset \Sigma(\mathrm{W} \cos \theta-\mathrm{ub} \sec \theta)+\Sigma \operatorname{cb} \sec \theta}{\Sigma \mathrm{W} \sin \theta} \\
& =\frac{0.364(1218675.51-614480.84)+415056.93}{397001.27} \\
& =1.599
\end{aligned}
$$

From Table 5. Slope stability analysis of Myittha saddle dam without pore water pressure (End of construction)

$$
\begin{aligned}
\mathrm{F}_{\mathrm{S}} & =\frac{\tan \emptyset(\Sigma \mathrm{W} \cos \theta)+\Sigma \operatorname{cbsec} \theta}{\Sigma \mathrm{W} \sin \theta} \\
& =\frac{0.6169(2,440,766.03)+511,040.22}{1,190,900.28} \\
& =1.69
\end{aligned}
$$

(d) Slope stability analysis by using computer

\begin{tabular}{|c|c|c|c|c|c|c|c|c|c|c|c|c|}
\hline$\stackrel{\mathscr{E}}{\bar{\varpi}} \dot{\mathrm{z}}$ & 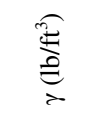 & $\underset{0}{E}$ & $\underset{\Xi}{\subseteq}$ & $\begin{array}{l}\hat{\theta} \\
\hat{3}\end{array}$ & 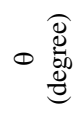 & $\begin{array}{l}0 \\
\text { : } \\
0\end{array}$ & $\begin{array}{l}0 \\
0 \\
0 \\
0 \\
3\end{array}$ & 疍 & $\begin{array}{l}\mathbb{U} \\
\ddot{d}\end{array}$ & $\begin{array}{l}0 \\
u \\
\tilde{D} \\
0 \\
0\end{array}$ & $\stackrel{0}{\stackrel{\Xi}{n}}$ & $\begin{array}{l}0 \\
.5 \\
3 \\
3\end{array}$ \\
\hline 1 & 127.42 & 49.92 & 28.19 & $179,311.13$ & $44^{\circ}$ & 0.7193 & $128,978.50$ & 935.299 & 1.3902 & $64,908.61$ & 0.6947 & $124,567.44$ \\
\hline 2 & 127.42 & 49.92 & 51.25 & $325,991.33$ & $37^{\circ}$ & 0.7986 & $260,336.68$ & 935.299 & 1.2522 & $58,465.38$ & 0.6018 & $196,181.58$ \\
\hline 3 & 127.42 & 49.92 & 61.5 & $391,189.59$ & $32^{\circ}$ & 0.8480 & $331,728.77$ & 935.299 & 1.1792 & $55,056.99$ & 0.5299 & $207,291.36$ \\
\hline 4 & 127.42 & 49.92 & 71.75 & $456,387.86$ & $28^{\circ}$ & 0.8829 & $402,944.84$ & 935.299 & 1.1326 & $52,881.24$ & 0.4695 & $214,274.10$ \\
\hline 5 & 127.42 & 49.92 & 68.68 & $436,860.18$ & $23^{\circ}$ & 0.9205 & $402,129.80$ & 935.299 & 1.0864 & $50,724.15$ & 0.3907 & $170,681.27$ \\
\hline 6 & 127.42 & 49.92 & 66.63 & 423,820 & $19^{\circ}$ & 0.9455 & 400,7 & 935.299 & 1.0576 & $49,379.48$ & 0.3256 & $137,995.96$ \\
\hline 7 & 127.42 & 49.92 & 53.3 & $339,030.98$ & $13^{\circ}$ & 0.9744 & $330,351.79$ & 935.299 & 1.0263 & $47,918.08$ & 0.2250 & $76,281.97$ \\
\hline 8 & 127.42 & 49.92 & 43.05 & $273,832.72$ & $11^{\circ}$ & 0.9816 & $268,794.20$ & 935.299 & 1.0187 & $47,563.23$ & 0.1908 & $52,247.28$ \\
\hline 0 & 127.42 & 49.92 & 25.63 & $163,027.47$ & $4^{\circ}$ & 0.9976 & $162,636.20$ & 935.299 & 1.0024 & $46,802.18$ & 0.0698 & $11,379.32$ \\
\hline \multirow[t]{2}{*}{10} & 127.42 & 39.924 & 10.25 & $52,142.94$ & $0^{\circ}$ & 1.0000 & $52,142.94$ & 935.299 & 1.0000 & $37,340.88$ & 0.0000 & 0.0000 \\
\hline & & & & & & & $2,440,766.03$ & & & $511,040.22$ & & $1,190,900.28$ \\
\hline
\end{tabular}
approach (SLOPE/W software)

Myittha main dam and saddle dam dimensions such as top width of dam, upstream and downstream side slopes, base width of the dam and height of the dam and soil properties such as unit weight of soil, cohesion and angle of internal friction are used as input data for slope stability analysis shown in Figures ( $2 \& 3)$ and Tables (1 \& 2).

Table 5. Slope stability analysis of Myittha saddle dam without pore water pressure (End of construction)

(c) Slope stability analysis of Myittha dam by analytical approach

The basic dimensions, elevations, slopes and the soil properties of embankment such as the unit weight of soil, cohesion, angle of internal friction, total height of the (e) Discussions

Summary results of safety factor for Myittha main dam and saddle dam are shown in Table (6). The obtained values of safety factor for Myittha dam are within the permissible limit. 
Table 6. Summary results of safety factor for Myittha main dam and saddle dam

\begin{tabular}{|c|c|c|c|c|c|c|c|c|}
\hline \multirow{3}{*}{$\begin{array}{l}\text { Loading } \\
\text { conditions }\end{array}$} & \multicolumn{8}{|c|}{ Factor of safety (Analytical Approach) } \\
\hline & \multicolumn{4}{|c|}{ Main dam } & \multicolumn{4}{|c|}{ Saddle dam } \\
\hline & \multicolumn{2}{|c|}{$\begin{array}{c}\text { Swedish circle } \\
\text { method }\end{array}$} & \multicolumn{2}{|c|}{$\begin{array}{c}\text { Modified } \\
\text { Bishop method }\end{array}$} & \multicolumn{2}{|c|}{$\begin{array}{c}\text { Swedish circle } \\
\text { method }\end{array}$} & \multicolumn{2}{|c|}{$\begin{array}{c}\text { Modified } \\
\text { Bishop method }\end{array}$} \\
\hline $\begin{array}{l}\text { End of } \\
\text { construction }\end{array}$ & $\mathrm{U} / \mathrm{S}$ & $\mathrm{D} / \mathrm{S}$ & $\mathrm{U} / \mathrm{S}$ & $\mathrm{D} / \mathrm{S}$ & $\mathrm{U} / \mathrm{S}$ & $\mathrm{D} / \mathrm{S}$ & $\mathrm{U} / \mathrm{S}$ & $\mathrm{D} / \mathrm{S}$ \\
\hline $\begin{array}{l}\text { with or } \\
\text { without } \\
\text { pore water } \\
\text { pressure }\end{array}$ & 2.039 & 2.26 & 1.69 & 2.28 & 2.243 & 1.34 & 1.536 & 2.07 \\
\hline $\begin{array}{l}\text { Steady-state } \\
\text { seepage }\end{array}$ & - & 1.56 & - & 1.58 & - & 1.599 & - & 1.52 \\
\hline $\begin{array}{l}\text { Sudden } \\
\text { drawdown }\end{array}$ & 1.243 & - & 1.263 & - & 1.204 & - & 1.227 & - \\
\hline \multirow{3}{*}{$\begin{array}{l}\text { Loading } \\
\text { conditions }\end{array}$} & \multicolumn{8}{|c|}{$\begin{array}{c}\text { Factor of safety (Computer approach with SLOPE/W } \\
\text { software) }\end{array}$} \\
\hline & \multicolumn{4}{|c|}{ Main dam } & \multicolumn{4}{|c|}{ Saddle dam } \\
\hline & \multicolumn{2}{|c|}{ U/S } & \multicolumn{2}{|c|}{$\mathrm{D} / \mathrm{S}$} & \multicolumn{2}{|c|}{$\mathrm{U} / \mathrm{S}$} & \multicolumn{2}{|c|}{$\mathrm{D} / \mathrm{S}$} \\
\hline End & \multicolumn{2}{|c|}{231} & \multicolumn{2}{|c|}{2.37} & \multicolumn{2}{|c|}{ ?. 34} & \multicolumn{2}{|c|}{208} \\
\hline
\end{tabular}
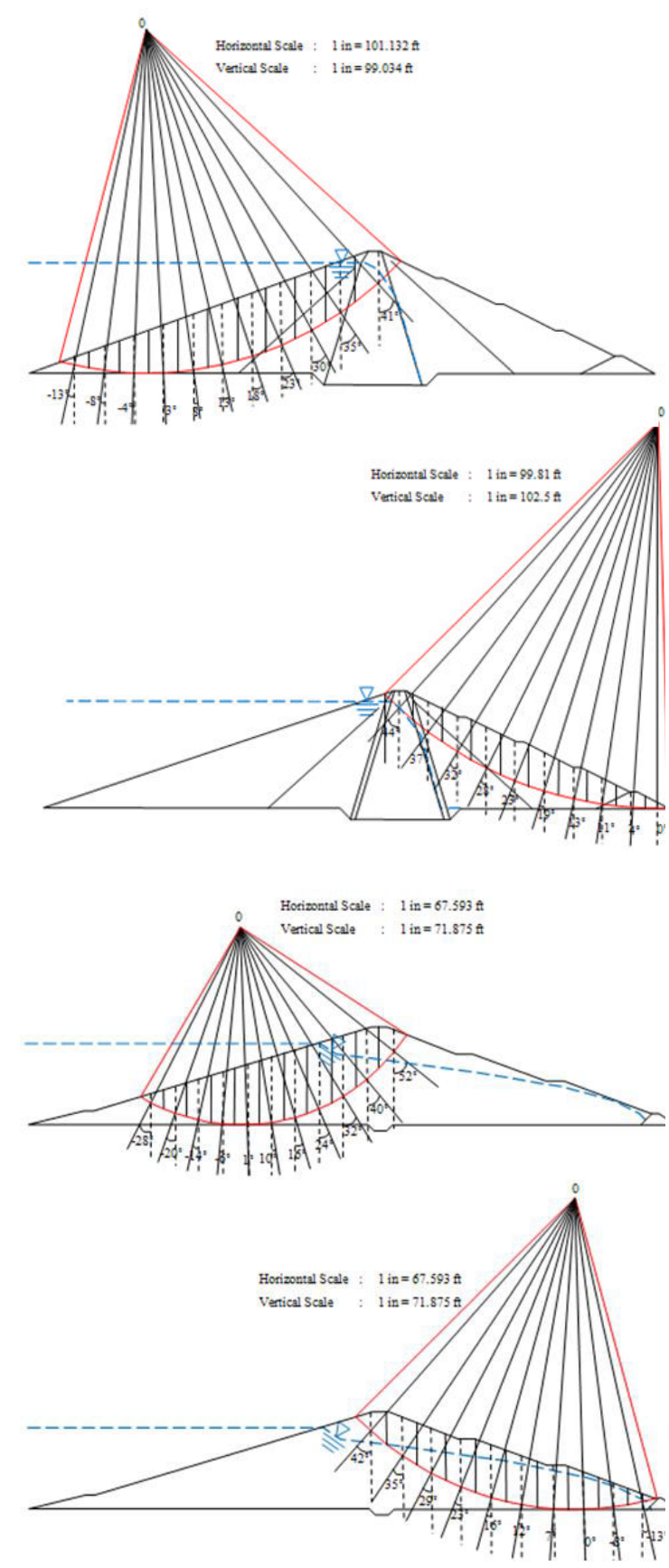

\section{CONCLUSION}

Methods used in this research are approved methods. All the values of the factor of safety are greater than the minimum accepted value [10]. The seepage through dam embankment and factors of safety of the Myittha dam are obtained within permissible limit. Rapid drawdown case is the most critical case compared to other cases of operations. For long term stability conditions of Myittha dam, surface movement indicators and piezometers should be installed to detect excessive deformation and excessive pore water pressure. The results of the analysis presented in this research confirm the safety of Myittha Dam against combined seepage and slope stability under all cases of operation. The source of the additional seepage should be determined and obtain taken as required. The location of upper line of seepage affects stability considerations and methods of controlling seepage. Toe drains are another method of controlling the line of seepage. The obtained seepage values should be compared and cross-checked with the seepage values after performing the grouting.

\section{Acknowledgements}

The author thanks the staffs at the Department of Irrigation for access to the data on the investigation stage of Myittha dam. I have to express my gratitude firstly to Dr. Day Wa Aung, Professor and Head of Geology Department, University of Yangon for his kind permission to carry out this paper presentation. I also

Figure 8. Stability analysis of slopes in Myittha main dam and saddle dam (U/S \& D/S) 
would like to thank the members of the AUN/SEED-Net JICA for their invitation to read the present paper on this occasion.

\section{REFERENCES}

[1] Dr. K. R. Arora, 2006, "Irrigation, Water Power and Water Resources Engineering"

[2] Irrigation Department, Geology Branch, Pre-Fesibility Study Report for Myittha Multipurpose Dam Project, July 2010

[3] Jan J. Tuma and M. ABDEL-Hady, 1973, "Engineering soil mechanics"

[4] J.Michael Duncan, Stephen G. Wright, 2005, "Soil Strength and Slope Stability"

[5] M. Das Braja, "Principles of Geotechnical Engineering" ( $2^{\text {nd }}$ Edition), 1990

[6] P. Gopal, Dr T. Kiran Kumar, "Slope stability and seepage analysis of earthern dam of a summer storage tank: A case study by using different approches". International Journal of Innovative Research in Advanced Engineering (IJIRAE), Vol.1, issue 12, December, 2014

[7] Qutaiba. G. Majeed, "Flow and deformation analysis of zoned earth dam by the finite element method"

[8] USACE, Engineering Manual, "Stability of Earth and Rock-Fill Dams," EM 1110-2-1902, 1 April, 1970

[9] USACE, Engineering Manual, "Seepage Analysis and Control for Dams," EM 1102-2-1901, 30 April, 1993

[10]USACE, Engineering Manual, "Slope Stability," EM 11102-1902, 31 October, 2003

[11]United States-Society on Dams, "Strength of Materials for Embankment Dams," February, 2007 